\title{
Optimisation of serine protease extraction from mango peel (Mangifera Indica Cv. Chokanan).
}

\begin{abstract}
This study investigated the possible relationship between the enzyme extraction variables, namely amount of buffer $(25-75 \mathrm{ml}, \mathrm{X} 1)$, temperature $\left(-20,25^{\circ} \mathrm{C}, \mathrm{X} 2\right)$ and mixing time $(1-3$ min, X3) on total protein (Y1), total activity (Y2), specific activity (Y3), storage stability (Y4), temperature stability (Y5) and $\mathrm{pH}$ stability (Y6) of serine protease from mango peel. It was found that there was significant $(\mathrm{p}<0.05)$ fit of the response surface models for all the response variables investigated. There was indication of high coefficient of determination (R2) values (between 0.954 and 1.000) in the regression models describing variations of the response variables. It was found that there was no significant $(p>0.05)$ difference between the experimental and predicted values. This ensured that the response surface models used to indicate property changes of serine protease as a function of enzyme extraction conditions were sufficient.
\end{abstract}

Keyword: Mango peel; Serine protease; Enzyme stability; Enzyme extraction. 